This item was submitted to Loughborough's Research Repository by the author.

Items in Figshare are protected by copyright, with all rights reserved, unless otherwise indicated.

Combinatorial study of Sn-Ti-W-O transparent conducting oxide thin films for photovoltaic applications

PLEASE CITE THE PUBLISHED VERSION

https://doi.org/10.1109/PVSC.2017.8521477

PUBLISHER

IEEE

VERSION

AM (Accepted Manuscript)

LICENCE

CC BY-NC-ND 4.0

REPOSITORY RECORD

Gona, Michael, Patrick J.M. Isherwood, Jake W. Bowers, and Michael Walls. 2019. "Combinatorial Study of Sn-ti-w-o Transparent Conducting Oxide Thin Films for Photovoltaic Applications”. figshare.

https://hdl.handle.net/2134/27050. 


\title{
Combinatorial study of Sn-Ti-W-O transparent conducting oxide thin films for photovoltaic applications
}

\author{
Michael N. Gona, Patrick J. M. Isherwood, Jake W. Bowers, John M. Walls \\ Centre for Renewable Energy Systems Technology (CREST), Holywell Park, The Wolfson School of \\ Mechanical, Electrical and Manufacturing Engineering, Loughborough University, Loughborough, \\ Leicestershire, LE11 3TU, United Kingdom
}

\begin{abstract}
- a combinatorial study of transparent conducting oxide thin films based on $\mathrm{SnO}_{2}-\mathrm{TiO}_{2}-\mathrm{WO}_{3}$ phase space is reported. These multinary oxide films were fabricated by magnetron reactive co-sputtering of tin monoxide ( $\mathrm{SnO}$ ), titanium (Ti) and tungsten (W) targets. $\mathrm{SnO}_{2}-\mathrm{TiO}_{2}-\mathrm{WO}_{3}$ film compositions with $\mathrm{Ti} / \mathrm{Sn}$ ratio $(0.02-0.12)$ and $\mathrm{W} /(\mathrm{Ti}+\mathrm{Sn})$ ratio $(0.02-0.25)$ were explored. The effect of oxygen partial pressure on composition, structure and optical properties was evaluated. High optical transparency above $80 \%$ across the visible spectrum was obtained for sputtered ternary $\mathrm{SnO}_{2}-\mathrm{TiO}_{2}$ oxide films for oxygen partial pressure $>\mathbf{1 9 . 4 \%}$. A positive correlation between optical bandgap and Ti/Sn ratio was observed. However, optical properties deteriorated as Ti-content increased in the asdeposited $\mathrm{SnO}_{2}-\mathrm{TiO}_{2}-\mathrm{WO}_{3}$ films. All studied as-deposited $\mathrm{SnO}_{2}-$ $\mathrm{TiO}_{2}-\mathrm{WO}_{3}$ thin films were found to be highly resistive. $\mathrm{X}$-ray diffraction data indicated no long-range structural order.

Index Terms - transparent conducting oxides, amorphous thin films, magnetron reactive sputtering, combinatorial technique
\end{abstract}

\section{INTRODUCTION}

Transparent conducting oxides (TCOs) perform critical functions in a wide range of opto-electronic devices. For instance, thin-film solar cells have traditionally used doped wide-bandgap TCOs such as $\mathrm{SnO}_{2}: \mathrm{F}, \mathrm{In}_{2} \mathrm{O}_{3}: \mathrm{Sn}$ and $\mathrm{ZnO}: \mathrm{Al}$ as transparent conducting electrodes, anti-reflection coatings and chemical barriers, etc. [1]-[6]. However, these crystalline TCOs need elevated deposition temperatures to optimize their physical, optical and charge-carrier transfer properties. This is a severe handicap for temperature-sensitive fabrication of next-generation organic and flexible photovoltaic devices. Amorphous TCOs thin films have been reported as potential alternatives to their conventional crystalline counterparts [7][9]. The approach follows the ability to tailor the physical, optical and charge-carrier transfer properties over a range of atomic compositions in the candidate amorphous thin films [10]-[13]. More recent studies of multicomponent oxides on InZnO [14], $\mathrm{ZnO}-\mathrm{In}_{2} \mathrm{O}_{3}-\mathrm{SnO}_{2}$ [15] and $\mathrm{ZnSnO}$ [16] have enunciated this concept. Potential amorphous TCO candidates include the nontoxic and environmental-friendly $\mathrm{TiO}_{2}-\mathrm{SnO}_{2}$ $\mathrm{WO}_{3}$ thin films. $\mathrm{TiO}_{2}$ and $\mathrm{SnO}_{2}$ have similar crystal structures, chemical bonds, bond-lengths and band energies [17]-[19]. Both are also remarkably stable oxides. Earlier reports on magnetron sputtered $\mathrm{WO}_{3}$ thin films have shown the possibility of modulating the physical, optical and electronic by judicial control of depositions conditions [20]-[22]. Tidoped $\mathrm{WO}_{3}$ [23], [24] and $\mathrm{W}$-doped $\mathrm{TiO}_{2}$ [25] studies have shown considerable possibilities that $\mathrm{W}-\mathrm{Ti}$ oxide films offer in optimizing the TCO thin-film structure, physical and optoelectronic properties for high-efficiency and low-cost nextgeneration photovoltaic devices. Magnetron reactive cosputtering technique [26] provides opportunity of producing $\mathrm{TiO}_{2}-\mathrm{SnO}_{2}-\mathrm{WO}_{3}$ thin films with controllable stoichiometry and composition. This report presented here investigates the structural and optical properties of sputtered $\mathrm{TiO}_{2}-\mathrm{SnO}_{2}-\mathrm{WO}_{3}$ thin films in relation to the composition and the effect of reactive gas $\left(\mathrm{O}_{2}\right)$ pressure.

\section{EXPERIMENTAL}

Film synthesis - compositionally graded Sn-Ti-W-O thin films were deposited by magnetron co-sputtering of ceramic SnO-target (99.99\% purity), Ti-target (99.99\% purity) and Wtarget (99.99\% purity). The films were deposited using an AJA International Orion $8 \mathrm{HV}$ sputter coater onto standard RCA pre-cleaned soda-lime glass (SLG) substrates (size $10 \mathrm{~cm}$ $\times 10 \mathrm{~cm}$ ) at room temperature. A metallic mask was used to create a $5 \times 5$ matrix with each sample size of $1.8 \mathrm{~cm} \times 1.8 \mathrm{~cm}$. The sputtering chamber base pressure was maintained below $10^{-7}$ Torr. The working pressure and Ar (sputtering gas) flow rate of $1 \mathrm{mT}$ Torr and 5SCCM respectively, were selected after preliminary investigations to determine the optimum deposition conditions. An oxygen $\left(\mathrm{O}_{2} 100 \%\right.$ purity) supply provided the reactive gas. The $\mathrm{O}_{2}$ flow rate was varied to control the oxygen partial pressure during depositions. Independent RF, DC and pulsed DC power sources were used to excite a three-gun assembly, shown in Fig. 1.

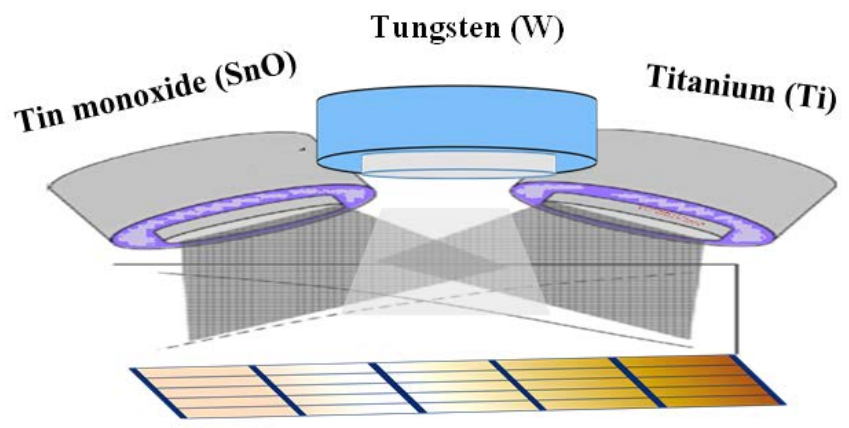

Fig. 1. The schematic of Tin monoxide (SnO), Tungsten (W) and Titanium (Ti) target arrangement in the magnetron sputtering chamber 
The target power was adjusted to control the sputtered flux condensing rate on stationary substrates. The coating duration was set to give the desired film thickness. Prior to each coating, each target was presputtered for 120s (with shutter closed) to remove target surface contaminants. All Sn-Ti-W-O thin films were deposited at room temperature and analyzed as-deposited.

Film analysis - At each coordinate on the $5 \times 5$ matrix, the analysis focused on structure, composition and optical properties. This allowed for rapid correlation of the results. Crystal structure was measured using a Bruker D2 phaser Xray diffractometer with a $\mathrm{Cu}-\mathrm{K} \alpha \mathrm{X}$-ray source and Lynxeye ${ }^{\mathrm{TM}}$ detector. A Cary 5000 UV-VIS-NIR spectrophotometer was used to determine the optical properties. An AMBIOS XP-2 profilometer was used to determine the film thickness. ThermoFisher Scientific ${ }^{\mathrm{TM}} \mathrm{K}$-Alpha ${ }^{\mathrm{TM}} \mathrm{X}$-ray photoelectron spectrometer (XPS) was used to probe the elemental contents of the samples.

\section{RESULTS AND DISCUSSION}

\section{A. RT magnetron sputtered $\mathrm{SnO}_{2}$ and $\mathrm{TiO}_{2}$ thin films}

Optical properties - The dependence of the deposition rate, physical and optical properties of RT sputtered $\mathrm{SnO}_{2}$ thin films on oxygen partial pressure (ppO2) was investigated. Fig. 1 shows behavior of the deposition rate, optical transmittance (in the visible spectrum) and optical bandgap with sputtering reactive gas.

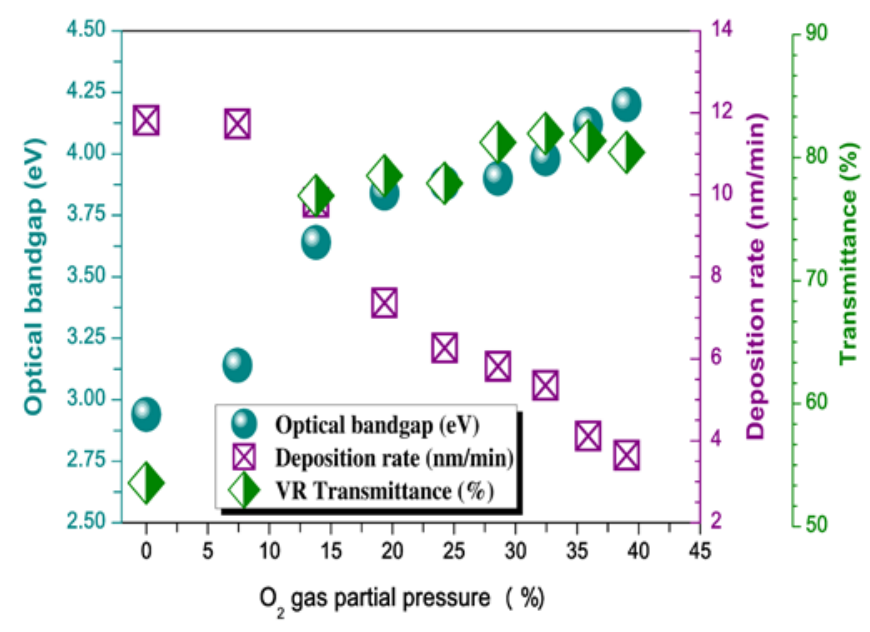

Fig. 2. Room temperature reactive sputtering of $\mathrm{SnO}_{2}$ thin films

The SnO target power was set at $180 \mathrm{~W}$ (RF supply). The sputtered $\mathrm{SnO}_{2}$ thin films exhibited an average thickness of $440 \mathrm{~nm}$. The average deposition rate decreased from a maximum of $12.5 \mathrm{~nm} / \mathrm{min}$ at $\mathrm{ppO}_{2}$ of $0 \%$ (100\% Ar plasma) to less than $3 \mathrm{~nm} / \mathrm{min}$ for $\mathrm{ppO}_{2}>40 \%$. The deposition rate rapidly decreases when even small amounts of $\mathrm{O}_{2}$ are added to an
Argon-plasma. This decreasing behavior has previously been reported when a $\mathrm{ZnO}$ and $\mathrm{SiO}_{2}$ targets have been sputtered using various $\mathrm{Ar} / \mathrm{O} 2$ gas mixtures [27][28]. However, optical properties of these films improved with the increase in $\mathrm{ppO}_{2}$. Optical transmittance in the visible spectrum of $\mathrm{SnO}_{2}$ films increased from $53 \%$ at $\mathrm{ppO}_{2}$ of $0 \%$ to $85 \%$ for a $\mathrm{ppO}_{2}$ of $40 \%$. This trend is mirrored by the optical bandgap behavior.

$\mathrm{TiO}_{2}$ thin films were deposited using a metallic Ti target (180W Pulsed DC). Fig. 2 shows variation of $\mathrm{TiO}_{2}$ film deposition rate, average VR transmittance and optical bandgap with $\mathrm{O}_{2}$ partial pressure $\left(\mathrm{ppO}_{2}\right)$.

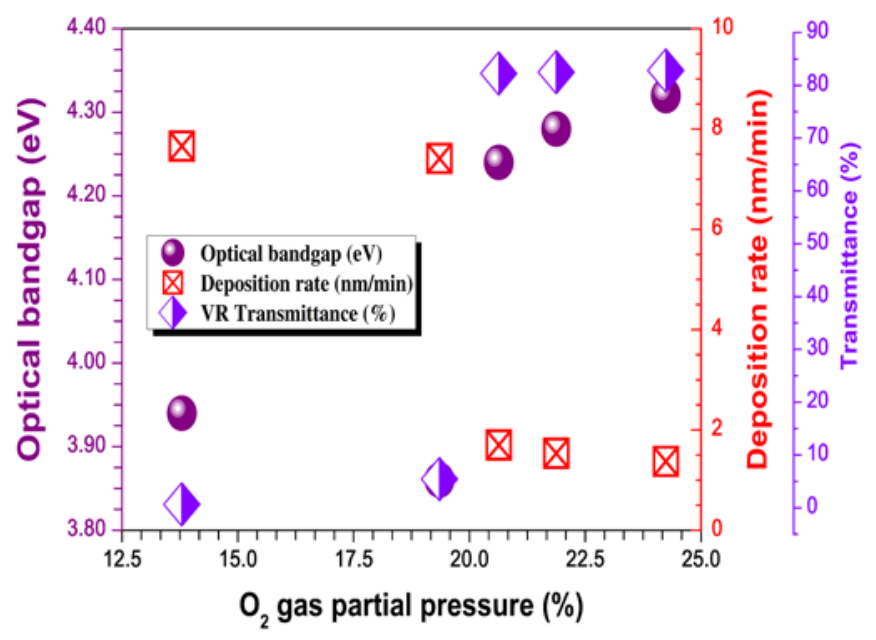

Fig. 3. Room temperature reactive sputtering of $\mathrm{TiO}_{2}$ thin films

There is a markedly abrupt drop in the $\mathrm{TiO}_{2}$ deposition rate at the $\mathrm{ppO}_{2}$ of $40 \%$. The deposition rate at averages $7.5 \mathrm{~nm} / \mathrm{min}$ for $\mathrm{ppO}_{2}<40 \%$ and then substantially reduces to below $2 \mathrm{~nm} / \mathrm{nm}$ thereafter. This sudden reduction in growth rate is most likely a result of $\mathrm{TiO}_{2}$ formation on the Ti target surface [29]. The $\mathrm{Ti}$ target transitions from operating in "metallic mode" with high yield rate to "oxide mode" low yield mode. The $\mathrm{TiO}_{2}$ thin films deposited in "metallic mode" conditions were less optically transparent (average VR transmittance below 10\%) compared to films deposited in the “oxide mode" region with average VR transmittance of $80 \%$.

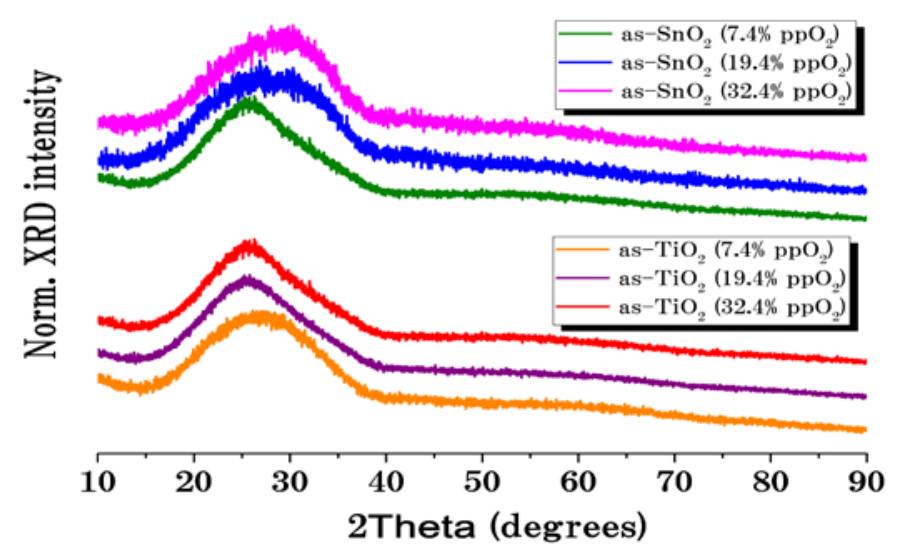

Fig. 4. XRD patterns of RT as-deposited $\mathrm{SnO}_{2}$ and $\mathrm{TiO}_{2}$ thin films 
Film structure - X-ray patterns of as-deposited $\mathrm{SnO}_{2}$ and $\mathrm{TiO}_{2}$ films deposited at oxygen partial pressure $\left(\mathrm{ppO}_{2}\right)$ levels of 7.4\%, 19.4\% and 32.4\% are shown in Fig. 4. Apart from the "broad-hump" shape from the glass substrate shown between $20^{\circ}$ and $40^{\circ}$, no sharp diffraction peaks can be seen in all the samples. These profiles are indicative of the absence of longrange structural order in the RT sputtered films. However, it is difficult to determine whether the as-deposited $\mathrm{SnO}_{2}$ and $\mathrm{TiO}_{2}$ films are amorphous or composed of nano-crystallites of only few nanometers which cannot be detected by XRD, because both structural phases exhibit a broad X-ray diffraction peak.

\section{B. RT magnetron sputtered $\mathrm{SnO}_{2}-\mathrm{TiO}_{2}$ thin films}

Fig. 5 shows the colour map of Ti/Sn ratio of a 5 x 5 spatial matrix for room temperature co-sputtered $\mathrm{Ti}$ ( $60 \mathrm{~W}$ DC power) and $\mathrm{SnO}$ (60W RF power). The deposition conditions were set at pressure of $1 \mathrm{mTorr}$, Ar-flow of 5SCCM and oxygen partial pressure $\left(\mathrm{ppO}_{2}\right)$ of $24.2 \%$. The average thickness of the sample was $270 \mathrm{~nm}$. XPS analysis showed Ti atomic percent with a maximum at $12.5 \%$ and high Sn atomic percent varying between $87.4 \%$ and $96.9 \%$.

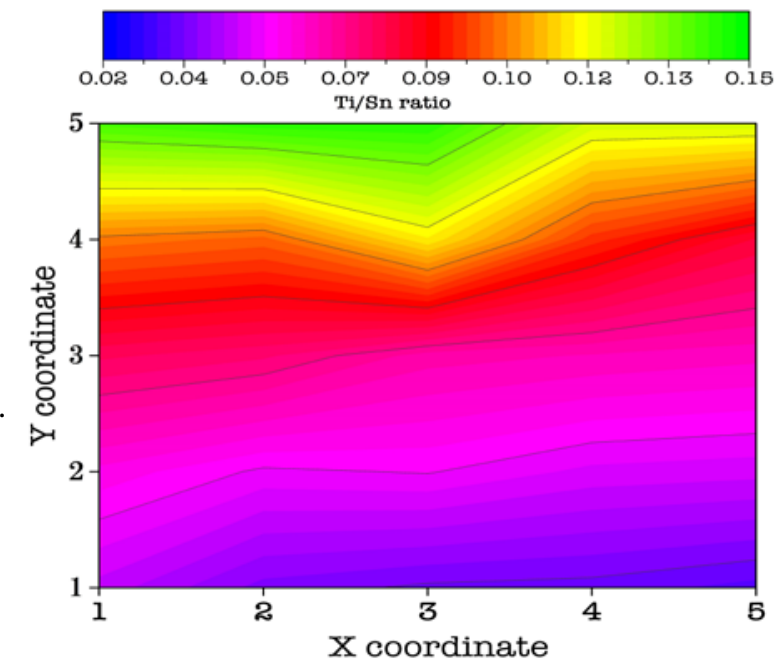

Fig. 5. Compositional mapping of the ratio Ti/Sn of a $10 \mathrm{~cm} \times 10 \mathrm{~cm}$ graded Sn-Ti-O thin film; each [x,y] corresponds to one $1.8 \mathrm{~cm} \times 1.8 \mathrm{~cm}$ cell

The Ti/Sn atomic ratio varies from 0.04 to 0.125 across the Sn-Ti-O film sputtered at a $\mathrm{ppO}_{2}$ of $24.2 \%$. The average Ti/Sn atomic ratio corresponds to the deposition rates of sputtered $\mathrm{TiO}_{2}$ and $\mathrm{SnO}_{2}$ fluxes on the substrate surface.

\section{Chemical composition and optical bandgap}

Fig. 6 (a) and Fig. 6 (b) Ti/Sn atomic ratio and optical bandgaps at selected coordinates $(1,1)(1,2),(1,3)$ and $(1,4)$ and $(2,1),(2,4)$ and $(2,5)$ respectively. The graphs show a positive correlation between the $\mathrm{Ti} / \mathrm{Sn}$ atomic ratio and optical bandgap in Sn-rich compositions. This result is in good agreement with optical transmittance data obtained from spectrophotometry and the literature [19], and provides a quick way of determining the composition of the $\mathrm{SnO}_{2}-\mathrm{TiO}_{2}$ films.

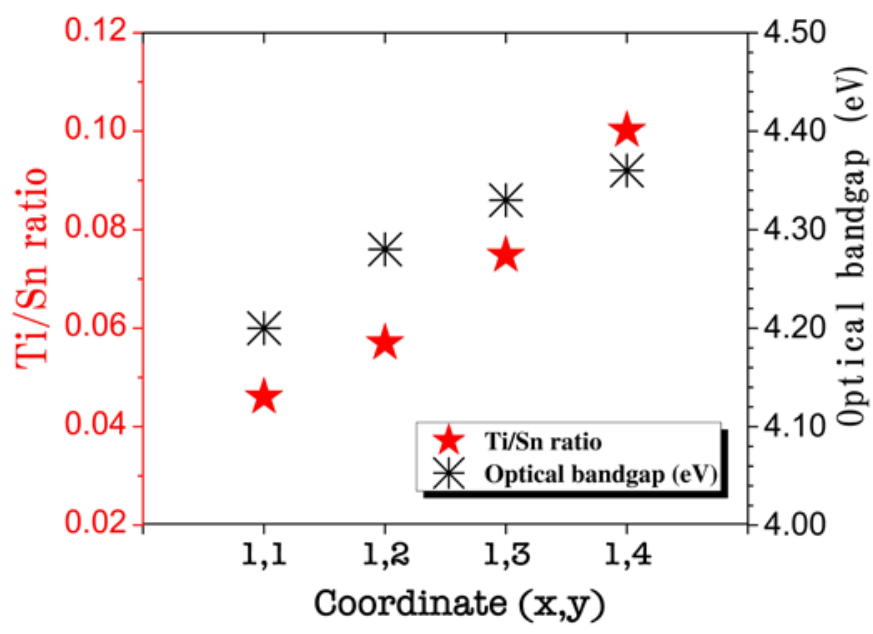

Fig. 6. Optical bandgap and Ti/Sn ratio at selected sample coordinates

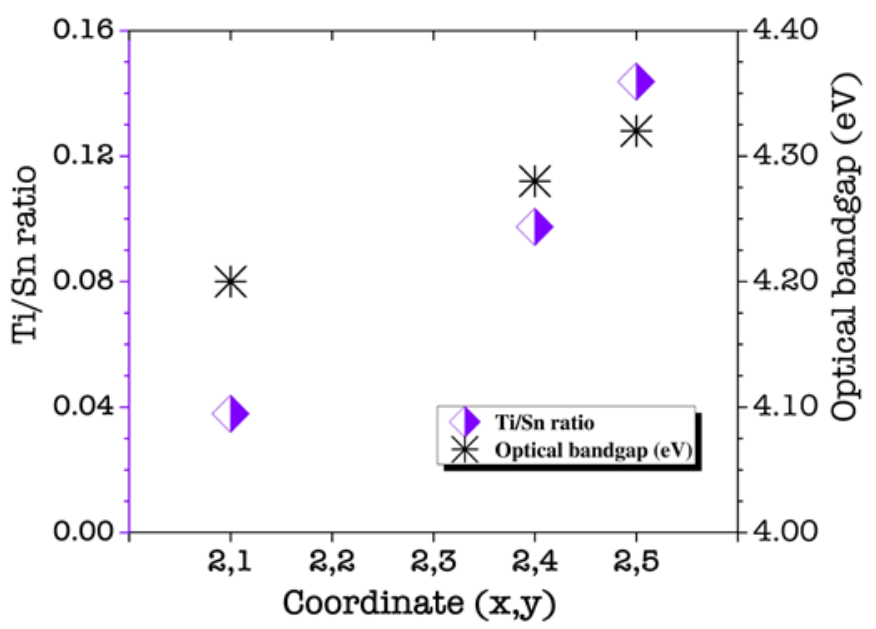

Fig. 7. Optical bandgap and $\mathrm{Ti} / \mathrm{Sn}$ ratio at selected coordinates

\section{RT magnetron sputtered $\mathrm{SnO}_{2}-\mathrm{TiO}_{2}-\mathrm{WO}_{3}$ thin films}

\section{Chemical composition and optical properties}

$\mathrm{X}$-ray photoelectron spectroscopy was used to obtain the chemical composition and valence state of the elements present in the grown films. The XPS survey spectra of the films identified the main constituents as Sn, Ti, W, O, and C. The carbon peak seen in the XPS spectra was due to carbon from air exposure before being placed in the XPS system.

Fig. 8, Fig.9 and Fig.10 show composition colour maps of the sputtered $\mathrm{SnO}_{2}-\mathrm{TiO}_{2}-\mathrm{WO}_{3}$ thin films deposited by cosputtering of W-target (120W RF), Ti-target (105W Pulsed $\mathrm{DC}$ ) and SnO-target (60W DC). The sputtering pressure was set at 1mTorr, with Ar-flow of 5SCCM with oxygen partial pressure $\left(\mathrm{ppO}_{2}\right)$ of $24.2 \%$. The average thickness of the deposited film was $492 \mathrm{~nm}$. XPS analysis showed average Ti 
atomic percent of $0.46 \%$, Sn atomic percent of $8.87 \%$ and $\mathrm{W}$ atomic percent of $11.54 \%$.

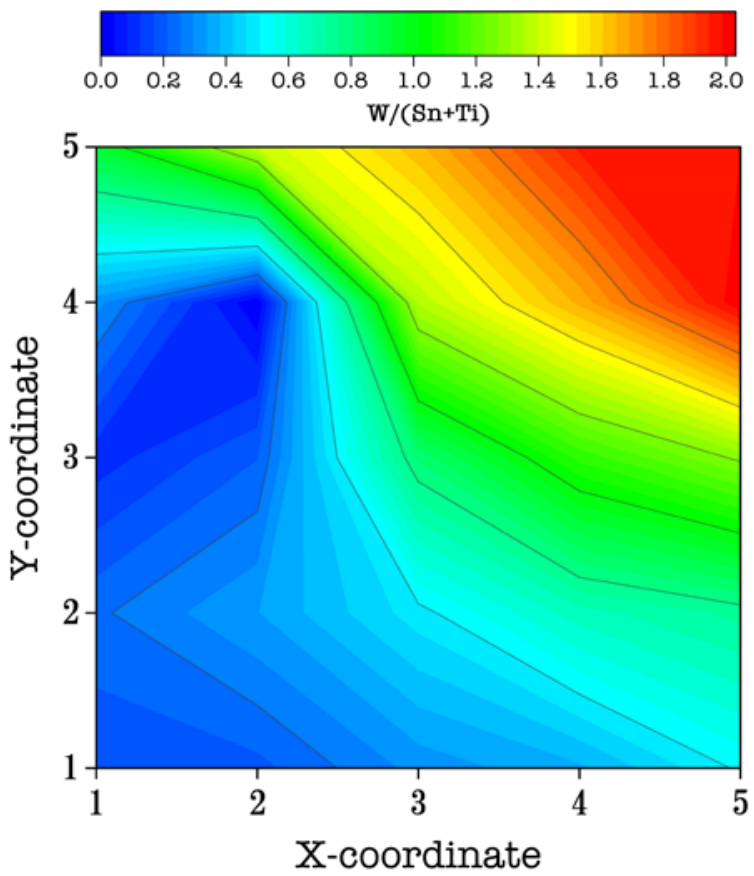

Fig. 8. Compositional mapping of the ratio $\mathrm{W} /(\mathrm{Sn}+\mathrm{Ti})$ of a $10 \mathrm{~cm} \times 10 \mathrm{~cm}$; each $[\mathrm{x}, \mathrm{y}]$ corresponds to one $1.8 \mathrm{~cm} \times 1.8 \mathrm{~cm}$ cell in $\mathrm{SnO}_{2}-\mathrm{TiO}_{2}-\mathrm{WO}_{3}$ thin films

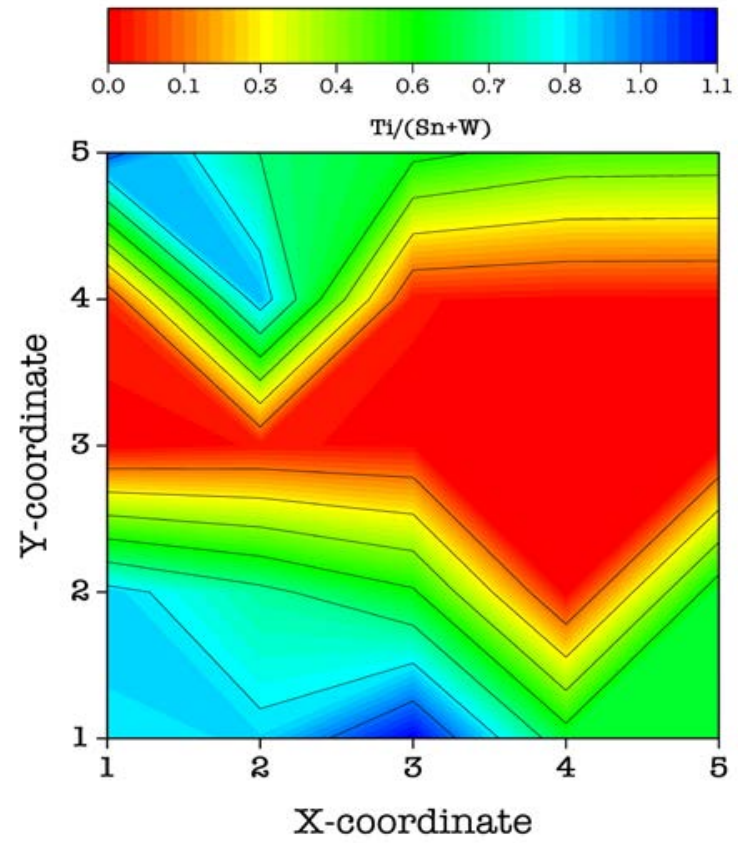

Fig. 9. Compositional mapping of the ratio $\mathrm{Ti} /(\mathrm{Sn}+\mathrm{W})$ of a $10 \mathrm{~cm} \times 10 \mathrm{~cm}$; each $[\mathrm{x}, \mathrm{y}]$ corresponds to one $1.8 \mathrm{~cm} \times 1.8 \mathrm{~cm}$ cell in $\mathrm{SnO}_{2}-\mathrm{TiO}_{2}-\mathrm{WO}_{3}$ thin films

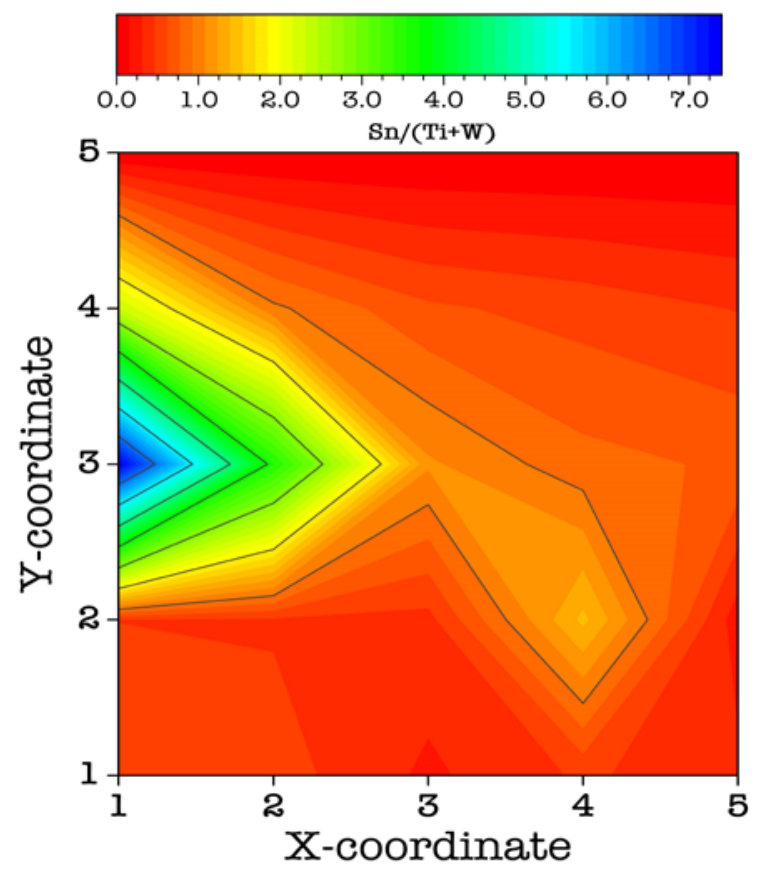

Fig. 10. Compositional mapping of the ratio $\mathrm{Sn} /(\mathrm{Ti}+\mathrm{W})$ of a $10 \mathrm{~cm} \times 10 \mathrm{~cm}$; each $[\mathrm{x}, \mathrm{y}]$ corresponds to one $1.8 \mathrm{~cm} \times 1.8 \mathrm{~cm}$ cell in $\mathrm{SnO}_{2}-\mathrm{TiO}_{2}-\mathrm{WO}_{3}$ thin films

Fig. 11 and Fig. 12 show optical transmittance and reflectance curves for respective coordinates on the matrix grid of the $\mathrm{SnO}_{2}-\mathrm{TiO}_{2}-\mathrm{WO}_{3}$ thin films. These films exhibited high transmittance $(>80 \%)$ across the visible spectrum. No free carrier absorption effects were observed. This was reflected in high sheet resistances observed in as-deposited $\mathrm{SnO}_{2}-\mathrm{TiO}_{2}-\mathrm{WO}_{3}$ films. Fig. 12 shows a marked decrease in transmittance as $\mathrm{Ti}$ atomic content increased.

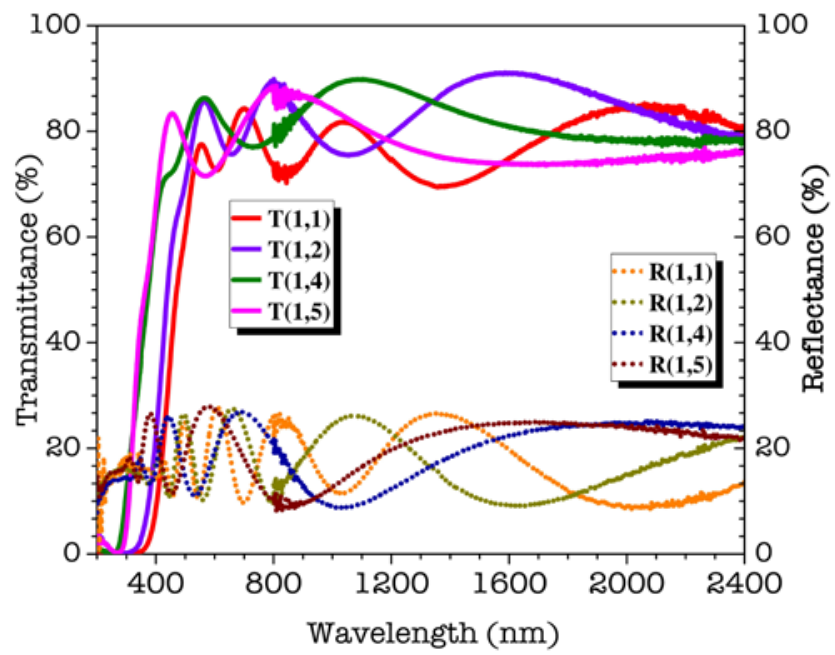

Fig. 11. Optical transmittance and reflectance plots of as-deposited $\mathrm{SnO}_{2}$ $\mathrm{TiO}_{2}-\mathrm{WO}_{3}$ thin films (at coordinates $(1,1),(1,2),(1,4)$ and $\left.(1,5)\right)$ 


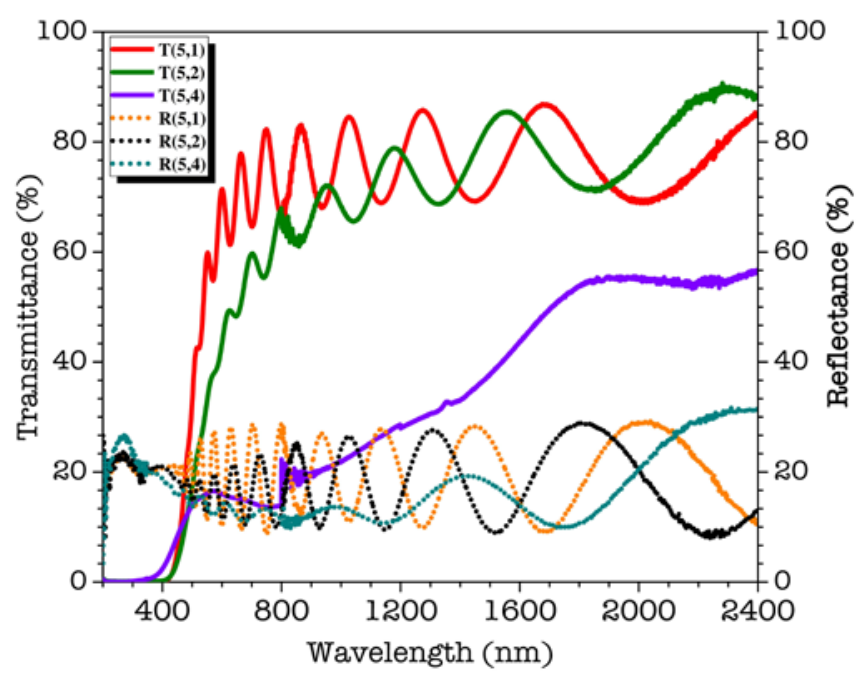

Fig. 12. Optical transmittance and reflectance plots of as-deposited $\mathrm{SnO}_{2}$ $\mathrm{TiO}_{2}-\mathrm{WO}_{3}$ thin films (at coordinates $(5,1),(5,2)$ and $(5,4)$ )

\section{SUMMARY}

Multinary oxide $\mathrm{SnO}_{2}-\mathrm{TiO}_{2}-\mathrm{WO}_{3}$ thin films were fabricated by reactive co-sputtering of $\mathrm{SnO}, \mathrm{Ti}$ and $\mathrm{W}$ targets. The structural and optical properties of compositional ranges $\mathrm{Ti} / \mathrm{Sn}$ of $(0.02-0.12)$ and $\mathrm{W} /(\mathrm{Ti}+\mathrm{Sn})$ of $(0.02-0.25)$ were explored. $\mathrm{XRD}$ data of the as-deposited $\mathrm{SnO}_{2}-\mathrm{TiO}_{2}-\mathrm{WO}_{3}$ thin films reveal the absence of long-range structural order. It was observed that film deposition rate for $\mathrm{Ti}, \mathrm{W}$ and $\mathrm{SnO}$ targets declined with an increase in $\mathrm{O}_{2}$ partial pressure. Sputtered films Optical transmittance in the visible spectrum of $\mathrm{SnO}_{2}$ films increased with oxygen partial pressure and this correlated well with the optical bandgap behavior. Optical properties deteriorated as Ti-content increased in the asdeposited $\mathrm{SnO}_{2}-\mathrm{TiO}_{2}-\mathrm{WO}_{3}$ films. All studied as-deposited $\mathrm{SnO}_{2}-\mathrm{TiO}_{2}-\mathrm{WO}_{3}$ thin films were found to be highly resistive.

\section{ACKNOWLEDGEMENT}

The authors wish to thank Dr. Keith Yendall and Rhiannon Buckton of the Loughborough Materials Characterization Centre, Loughborough University for their assistance with XRD and XPS measurements, respectively. M. N. Gona gratefully acknowledges financial support from the Commonwealth Scholarship Commission (UK) for $\mathrm{PhD}$ scholarship.

\section{REFERENCES}

[1] N. K. Temizer, S. Nori, and J. Narayan, "Ga and Al doped zinc oxide thin films for transparent conducting oxide applications : Structure-property correlations $\mathrm{Ga}$ and $\mathrm{Al}$ doped zinc oxide thin films for transparent conducting oxide applications:
Structure-property correlations,” vol. 23705, 2014.

[2] M. Wuttig, "Correlation between structure , stress and deposition parameters in direct current sputtered zinc oxide films,” no. May, 2016.

[3] J. Herrero, "Comparison study of ITO thin films deposited by sputtering at room temperature onto polymer and glass substrates,” vol. 481, pp. 129-132, 2005.

[4] T. Minami, "Present status of transparent conducting oxide thin-film development for Indium-Tin-Oxide ( ITO ) substitutes,” vol. 516, pp. 5822-5828, 2008.

[5] H. Search, C. Journals, A. Contact, M. Iopscience, and I. P. Address, "Study on Crystallinity of Tin-Doped Indium Oxide Films Sputtering Deposited by DC Magnetron,” vol. 1870, 1870.

[6] B. Stjerna, E. Olsson, C. G. Granqvist, B. Stjerna, and E. Olsson, "Optical and electrical properties of radio frequency sputtered tin oxide films doped with oxygen vacancies, F, Sb , or Mo Optical and electrical properties of radio frequency films doped with oxygen vacancies , F , Sb , or MO sputtered tin oxide," vol. 3797, no. 1994, 2009.

[7] A. Walsh, J. L. F. Da Silva, S. Wei, and C. Postal, "Interplay between Order and Disorder in the High Performance of Amorphous Transparent Conducting Oxides,” no. 17, pp. 5119-5124, 2009.

[8] H. Hosono, "Ionic amorphous oxide semiconductors : Material design , carrier transport , and device application,” vol. 352, pp. 851-858, 2006.

[9] A. Walsh, J. L. F. Da Silva, S.-H. Wei, and C. Postal, "Multicomponent Transparent Conducting Oxides: Progress in Materials Modelling,” pp. 1-12, 2011.

[10] F. Funabiki, T. Kamiya, and H. Hosono, "Doping effects in amorphous oxides,” pp. 447-457, 2012.

[11] E. A. Davis and N. F. Mott, "Conduction in non-crystalline systems V . Conductivity , optical absorption and photoconductivity in amorphous semiconductors,” vol. 8086, no. May, 2017.

[12] A. Takagi, K. Nomura, H. Ohta, H. Yanagi, T. Kamiya, M. Hirano, and H. Hosono, "Carrier transport and electronic structure in amorphous,” vol. 486, pp. 38-41, 2005.

[13] X. Zhou, J. Xu, L. Yang, X. Tang, Q. Wei, and Z. Yu, “Amorphous In_2Ga_2ZnO_7 films with adjustable structural, electrical and optical properties deposited by magnetron sputtering,” Opt. Mater. Express, vol. 5, no. 7, p. 1628, 2015.

[14] M. F. A. M. Van Hest, M. S. Dabney, J. D. Perkins, and D. S. Ginley, "High-mobility molybdenum doped indium oxide," vol. 496, pp. 70-74, 2006.

[15] C. A. Hoel, T. O. Mason, and K. R. Poeppelmeier, "Transparent Conducting Oxides in the ZnO-In2O3 -SnO2 System,” Chem. Mater., vol. 22, pp. 3569-3579, 2010.

[16] C. W. Gorrie, M. Reese, J. D. Perkins, M. F. A. M. Van Hest, J. L. Alleman, M. S. Dabney, B. To, D. S. Ginley, J. J. Berry, M. F. A. M. Van Hest, J. L. Alleman, M. S. Dabney, B. To, D. S. Ginley, J. J. Be, M. F. A. M. Van Hest, J. L. Alleman, M. S. Dabney, B. To, D. S. Ginley, and J. J. Berry, “Transparent 
conducting contacts based on zinc oxide substitutionally doped with gallium," Conf. Rec. IEEE Photovolt. Spec. Conf., pp. 79, 2008.

[17] M. Dou and C. Persson, "Comparative study of rutile and anatase $\mathrm{SnO} 2$ and $\mathrm{TiO} 2$ 2: Band-edge structures, dielectric functions, and polaron effects,” J. Appl. Phys., vol. 113, no. 8, 2013.

[18] T. Hitosugi, N. Yamada, S. Nakao, Y. Hirose, and T. Hasegawa, "Properties of TiO2-based transparent conducting oxides,” Phys. Status Solidi, vol. 207, no. 7, pp. 1529-1537, 2010.

[19] S. Chen, J. R. Manders, S. Tsang, and F. So, "Metal oxides for interface engineering in polymer solar cells,” pp. 24202-24212, 2012.

[20] M. Vargas, D. M. Lopez, N. R. Murphy, J. T. Grant, and C. V. Ramana, "Effect of W-Ti target composition on the surface chemistry and electronic structure of WO3-TiO2 films made by reactive sputtering,” Appl. Surf. Sci., vol. 353, pp. 728-734, 2015.

[21] M. Vargas, E. J. Rubio, A. Gutierrez, and C. V Ramana, "WO3 films made by co-sputter deposition Spectroscopic ellipsometry determination of the optical constants of titanium-doped WO 3 films made by co-sputter deposition,” vol. 133511, 2014.

[22] S. F. E. Akbarnejad and A. S. Elahi, "Growth and Characterization of Tungsten Oxide Thin Films using the
Reactive Magnetron Sputtering System,” J. Inorg. Organomet. Polym. Mater., vol. 26, no. 4, pp. 889-894, 2016.

[23] P. S. Patil, S. H. Mujawar, A. I. Inamdar, and P. S. Shinde, "Structural , electrical and optical properties of TiO 2 doped WO 3 thin films,” vol. 252, pp. 1643-1650, 2005.

[24] C. V Ramana, G. Baghmar, E. J. Rubio, and M. J. Hernandez, "Optical Constants of Amorphous , Transparent TitaniumDoped Tungsten Oxide Thin Films,” 2013.

[25] D. Chen, G. Xu, L. Miao, L. Chen, S. Nakao, and P. Jin, "Wdoped anatase TiO 2 transparent conductive oxide films: Theory and experiment,” J. Appl. Phys., vol. 63707, no. 2010, pp. 2-6, 2015.

[26] W. D. Sproul, D. J. Christie, and D. C. Carter, "Control of reactive sputtering processes,” vol. 491, pp. 1-17, 2005.

[27] C. R. Aita, A. J. Purdes, K. L. Lad, and P. D. Funkenbusch, “The effect of $\mathrm{O} 2$ on reactively sputtered zinc oxide," J. Appl. Phys., vol. 51, no. 10, pp. 5533-5536, 1980.

[28] C. R. Aita and N. C. Tran, "Sputter deposition of platinum films in argon/oxygen and neon/oxygen discharges,” J. Appl. Phys., vol. 56, no. 4, pp. 958-963, 1984.

[29] R. Snyders, J. Dauchot, and M. Hecq, "Synthesis of Metal Oxide Thin Films by Reactive Magnetron Sputtering in Ar / O 2 Mixtures: An Experimental Study of the Chemical Mechanisms,” pp. 113-126, 2007. 